ORIGINAL ARTICLE

\title{
Dendrochronology of maritime pine in the middle of the Atlantic Ocean
}

\author{
Joana Vieira*, Filipe Campelo, Cristina Nabais \\ Centre for Functional Ecology, Department of Life Sciences, University of Coimbra, Calçada Martim de Freitas, 3000-456 Coimbra, Portugal
}

\section{A R T I C L E I N F O}

\section{Keywords:}

Azores Archipelago

Intra-annual density fluctuations

Macaronesia

Oceanic islands

Pico Island

\begin{abstract}
A B S T R A C T
The Azores Archipelago, located in the North Atlantic Ridge, experiences heavy rainfall and mild temperatures with weak seasonal differences due to oceanic influence. To our knowledge, there have been no dendrochronological studies in the Azores. The aim of this study is to explore the dendrochronological potential of Pinus pinaster Ait. growing in this archipelago and to determine what limiting factor is regulating tree growth. To do so, we have sampled adult maritime pine trees growing in a plantation, in the Pico island of the Azores.

Tree ring boundaries were not always easily distinguished, suggesting that in some years cambial activity did not stop during winter. Despite this, it was possible to successfully crossdate the tree-ring series and to establish a tree-ring width chronology with a strong common signal. Climatic correlations revealed a positive response to spring precipitation but no temperature signal in the tree-ring width chronology. Tree-ring width was also negatively correlated with the North Atlantic Oscillation (NAO) and the sea level pressure (SLP) in May - June.

Intra-annual density fluctuations (IADFs), which are anatomical features formed in response to variations in environmental conditions during the growing season, were present in $85 \%$ of the tree rings. IADFs were identified based on its position within the ring: type $\mathrm{E}^{+}$, characterized as a transition wood from early- to latewood; type L, the most frequent, characterized as earlywood-like cells within latewood; and type $\mathrm{L}^{+}$, characterized as earlywood-like cells between latewood and earlywood of the next tree ring. Each IADF type presented a unique climatic signal: type $\mathrm{E}^{+}$was positively correlated with early summer precipitation and early spring temperature; type $\mathrm{L}$ was positively correlated with early autumn precipitation and temperature; and type $\mathrm{L}^{+}$was positively correlated with late autumn precipitation.

In conclusion, the tree-ring width chronology established for maritime pine growing in the Pico Island of Azores contains a clear climatic signal for spring precipitation, whereas IADFs frequency correlated better with precipitation later in the growing season. For this reason, we suggest that IADFs should be included in future dendrochronological studies in the Macaronesia Biogeographical region since they can improve the climatic signal present in tree-ring width chronologies.
\end{abstract}

\section{Introduction}

The Azores are a Portuguese archipelago of volcanic origin located in the North Atlantic Ridge between the latitudes of $36^{\circ} 45^{\prime} \mathrm{N}$ and $39^{\circ} 43^{\prime}$ S. It is part of Macaronesia, a biogeographical entity that includes four archipelagos: Cape Verde, the Canary Islands, Madeira and the Azores (Myers et al., 2000). The climate of Macaronesia varies from sub-tropical to arid in Cape Verde and the Canary Islands, and to temperate-Mediterranean in Madeira and the Azores. Due to the influence of the warm Gulf Stream and the Azores Anticyclone, the Azores present warm temperatures with little variability throughout the year (Cunha et al., 2010; Santos et al., 2004). Precipitation in the Azores is highly influenced by the North Atlantic Oscillation (NAO), both in winter and summer, with seasons dominated by negative NAO phases presenting higher mean precipitation values (Hernández et al., 2016).
The strong influence of the Atlantic Ocean also makes these islands wetter, windier and cloudier than the continent.

To our knowledge, the only dendrochronological studies performed in Macaronesian islands were in Tenerife, belonging to the Canary archipelago, using the native species Pinus canariensis C. Sm. (Jonsson et al., 2002; Pérez-De-Lis et al., 2011; Rozas et al., 2013, 2011b). Jonsson et al. (2002) found that the tree-ring growth in P. canariensis growing in the upper tree limit, was dependent on the previous year precipitation and temperature during the four previous years. Rozas et al. (2013) also studied the climatic response of $P$. canariensis in trees growing along an altitudinal gradient in the windward and leeward slopes. They observed that tree-growth was highly influenced by trade winds and by the North Atlantic Oscillation (NAO). Although part of Macaronesia, the climate in the Azores is very different from the arid Canary Islands, thus it would be very interesting to determine what

\footnotetext{
* Corresponding author.

E-mail address: joana.vieira@uc.pt (J. Vieira).
} 
climatic factors are limiting tree growth and whether if it is possible to do a dendroclimatology study in these islands.

Maritime pine (Pinus pinaster Ait.) was introduced in the Pico Island of Azores after the last volcanic eruption in 1718 (Governo Regional dos Açores, 2002). Nowadays maritime pine is an important forest species in this island and the second most used for wood production. The Azores present quite different climatic conditions when compared with the native distribution of maritime pine in the Mediterranean region and Atlantic coast of southwest Europe (EUFORGEN, 2009). Dendrochronological studies performed on its native region showed that tree growth was enhanced by previous winter and spring precipitation and constrained by summer drought (Campelo et al., 2015; Nabais et al., 2014; Rozas et al., 2011a; Vieira et al., 2009). The climate in the Azores Archipelago is, however, milder than the Mediterranean climate. Thus it would be interesting to determine the climatic signal, if any, present in maritime pine trees growing in the Azores.

In its native distribution maritime pine frequently presents false rings or intra-annual density fluctuations (IADFs). Intra-annual density fluctuations are variations in wood density (lumen diameter to cell wall thickness ratio) that are formed in response to variations in environmental conditions during the growing season, as can be easily observed by comparing seasonal environmental conditions with the intra-ring pattern of tracheid features (Campelo et al., 2016; Carvalho et al., 2015). IADFs can be present in earlywood and latewood, being defined as latewood-like cells within earlywood (IADF type E) or by earlywoodlike cells within latewood (IADF type L; Campelo et al., 2007), respectively. In trees growing in the Mediterranean region, earlywood IADFs are formed in response to a drought period during spring and latewood IADFs by above average precipitation in fall (Battipaglia et al., 2016; Campelo et al., 2007). Due to its refined climatic signal, IADFs have been recently used to improve the climatic signal of treering width chronologies (Campelo et al., 2007; Vieira et al., 2010; Wimmer, 2002). Although maritime pine usually presents a high frequency of IADFs in the Atlantic coast of Portugal and Spain (Rozas et al., 2011c; Vieira et al., 2010), it is not known whether the Azores climate will trigger the formation of such anatomical features.

Our aim is to explore the dendrochronological potential of maritime pine in the context of Macaronesian Dendrochronology. The objectives are to 1) determine the limiting factors for tree growth in the Azores; 2) determine whether IADFs are formed and 3) what climatic factors trigger its formation.

\section{Material and methods}

\subsection{Study site}

The study site is located in the North side of the Pico Island, in the Azores Archipelago (Fig. 1, 38.54208 N; 28.39906 W; $175 \mathrm{~m}$ a.s.l.). Pico Island is the second largest island in the archipelago being $42 \mathrm{~km}$ long and $15.2 \mathrm{~km}$ wide covering $447 \mathrm{~km}^{2}$. The Azores Archipelago is composed of nine islands distributed in three groups: the western group (Flores and Corvo), the Central group (Pico, Faial, Terceira, São Jorge and Graciosa) and the Eastern group (São Miguel and Santa Maria). Pico Island is the second largest and the youngest: it only emerged from the sea 300.000 years ago (Madeira, 1998). The last volcanic eruption in the Pico Island was in 1718 and created a vast basaltic lava area in the northeast part of the island. This area was later populated with maritime pine (Pinus pinaster Ait.) by the Forest Services in order to protect the coastal line from erosion (). The study site is located in this forest, a plantation dominated by maritime pine with an understory of sparsely distributed shrubs of the species Myrica faya Ait., Erica azorica (Seub.) Hochst., Picconia azorica (Tutin) Knobl., Frangula azorica Tutin and Laurus azorica Franco.

The climate in the Azores Archipelago is of Mediterranean type, characterized by a narrow annual temperature range, high precipitation and a moderate summer drought (Fig. 2). The annual average temperature is $17.2^{\circ} \mathrm{C}$ and total precipitation is $1003 \mathrm{~mm}$ (annual averages calculated for the period $1961 \& 2010$ from monthly data downloaded from the Royal Netherlands Meteorological Institute, http://www.climexp.knmi.nl/). In the coldest month (February), the average temperature if of $11.3^{\circ} \mathrm{C}$ and in the warmest month (August), $25.0^{\circ} \mathrm{C}$. Precipitation presents a seasonal distribution, mainly occurring in the fall and winter months (Fig. 2). In Spring and Summer precipitation decreases and July is the driest month $(33.1 \mathrm{~mm})$.

\subsection{Tree-ring data}

In July 2011, 30 co-dominant $P$. pinaster trees were sampled from an area of approximately 5 he. The selected trees presented an average diameter at breast height of $46.4 \mathrm{~cm}$, an average height of $15.2 \mathrm{~m}$ and 40 years of age. Two cores were taken from each tree, at breast height, from the north-south directions. The increment cores were later glued to wood supports and sanded with progressively finer grades of sandpaper to produce a polished surface on which tree-ring boundaries and individual tracheids were clearly visible under magnification (Stokes and Smiley, 1996). Tree rings were measured to the nearest $0.01 \mathrm{~mm}$ using the linear table LINTAB (Frank Rinn S.A, Heidelberg, Germany) and the program TSAP-Win (Rinn, 2003), and then crossdated using standard dendrochronology techniques (Stokes and Smiley, 1996).

From the initial 30 trees, only 22 were included in the analysis. Trees presenting a correlation with the mean chronology below 0.5 or less than 20 tree rings were excluded from further analysis. A one-step detrending procedure was applied to each tree-ring series to remove age-related growth trends and competition using the packages "dplR" (Bunn, 2008) and "detrendeR" (Campelo et al., 2012\& http://cran.rproject.org) for the $\mathrm{R}$ freeware program. The detrending procedure consisted of fitting a smoothing cubic spline curve with a $50 \%$ frequency cut-off and response period of 25 years to each individual ringwidth series. Detrended series were used to produce a standard chronology using a biweight robust estimate of the mean to reduce the influence of outliers (Briffa and Cook, 1990). An autoregressive model was applied to this chronology to remove temporal autocorrelation and maximize the common inter-annual signal. Mean sensitivity (MS) and the first-order auto-correlation (AR1) were calculated on individual series (raw and detrended) and averaged to measure the year-to-year variability and how the current-year growth is affected by the previous year's growth, respectively. Chronology quality was evaluated using the expressed population signal (EPS) that indicates the degree to which a given chronology portrays a hypothetical perfect chronology (Wigley et al., 1984).

\subsection{Intra-annual density fluctuations}

Cores were visually examined for IADFs in the common interval (1961 \& 2010) using a stereomicroscope (magnification up to $25 \mathrm{x}$ ). IADFs were identified based on its radial position within the tree ring following the classification proposed by Campelo et al. (2007). IADFs were classified as follows: type $\mathrm{E}^{+}$, characterized as transition wood with intermediate characteristics between earlywood and latewood, in terms of lumen area and cell wall thickness of the tracheids and located in the transition from early- to latewood (Fig. 3); IADF type L, characterized by the presence of earlywood like cells within latewood (Fig. 3); and IADF type $\mathrm{L}^{+}$, characterized by transition wood from latewood to the earlywood of the next tree ring (Fig. 3). Since it was common to observe more than one IADF per tree ring the following combinations were also analyzed: $\mathrm{E}^{+} \mathrm{L}, \mathrm{E}^{+} \mathrm{L}^{+}$and $\mathrm{LL}^{+}$. IADFs and their combinations were registered on each core.

The frequency of IADFs per year, $F$, was calculated as follows:

$F=N / n$

where $N$ is the number of cores that presented a certain type of IADF in a given year and $n$ is the total number of observed cores. To adjust for 


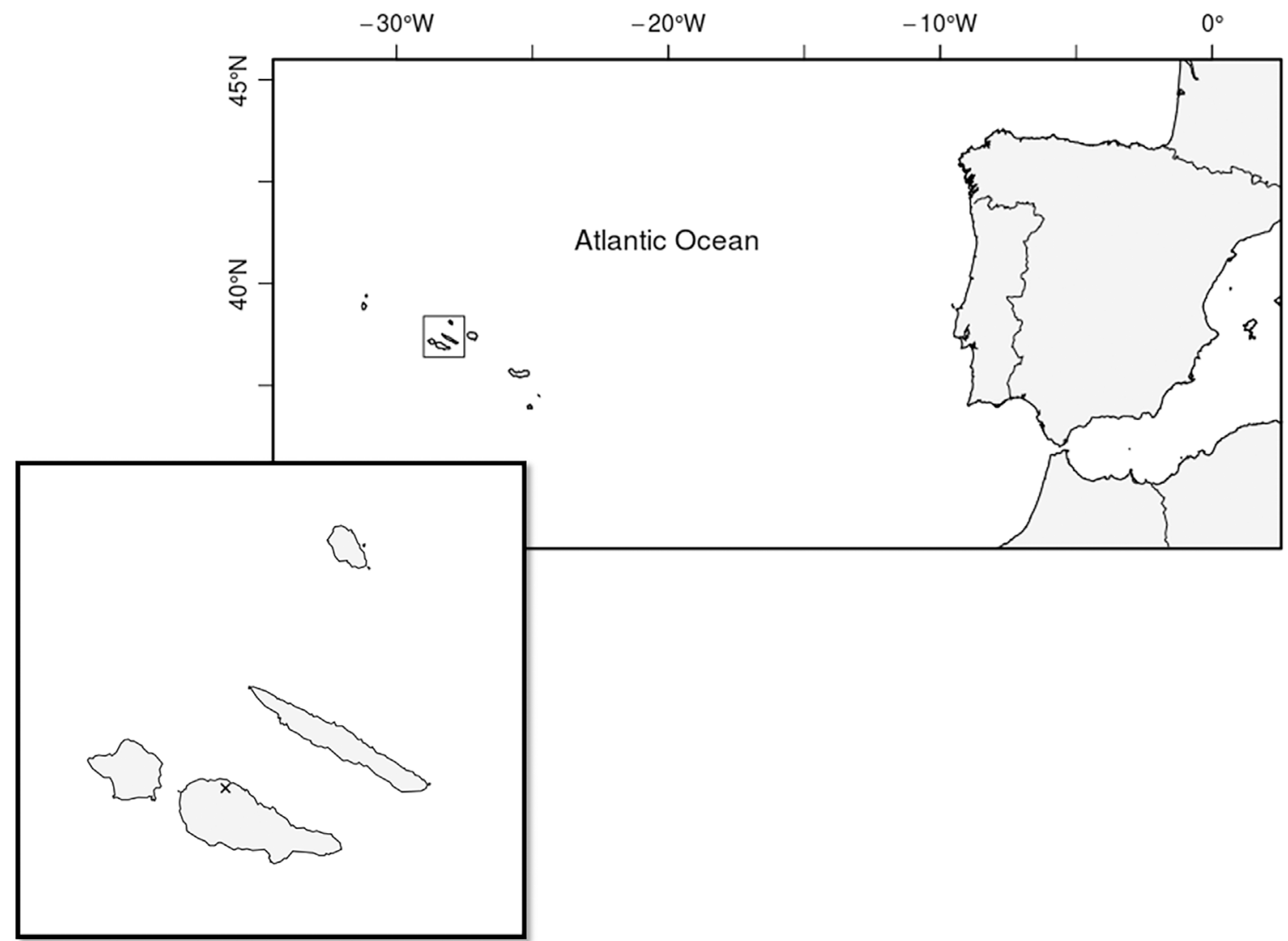

Fig. 1. Location of the study site $(\mathrm{x})$ in the Pico Island of the Azores Archipelago, Portugal.

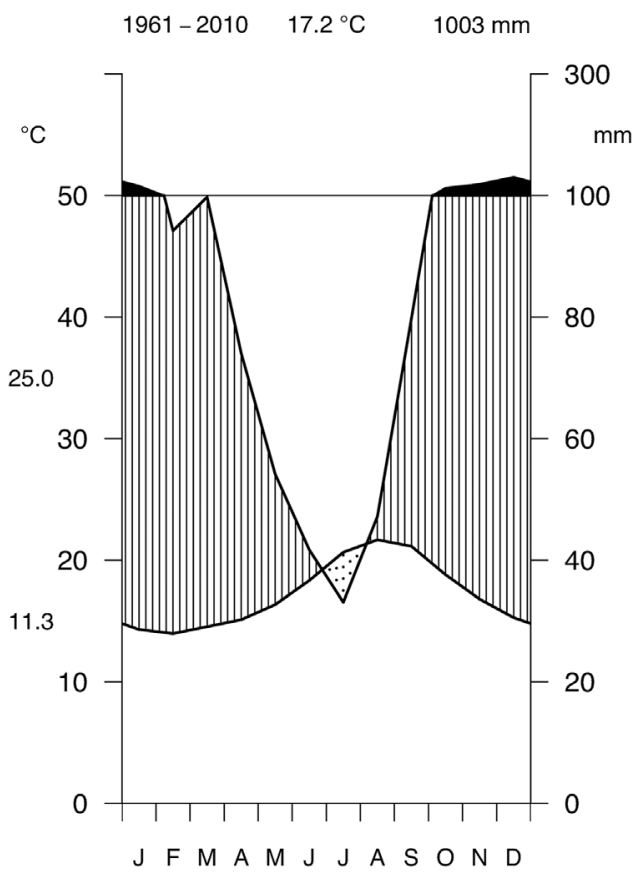

Fig. 2. Climatic diagram for the period 1961 \& 2010. The diagram consists of the monthly mean temperature $\left({ }^{\circ} \mathrm{C}\right)$ and total precipitation $(\mathrm{mm})$. Data was downloaded from the Royal Netherlands Meteorological Institute (http://www.climexp.knmi.nl).

the variation in the sample depth over time a stabilized frequency was calculated using the adjustment proposed by Osborn et al. (1997):

$f=F n^{0.5}$

where $f$ is the stabilized IADF frequency.

\subsection{Climatic signal in tree-ring width and IADFs}

The influence of mean temperature, precipitation, Sea Level Pressure (SLP) and the North Atlantic Oscillation (NAO) was investigated on tree-ring width for the common period (from 1961 to 2010), using correlation analysis. NAO and SLP indices were downloaded from the Royal Netherlands Meteorological Institute (http:// www.climexp.knmi.nl/). Pearson's correlations were calculated between tree-ring width and the climatic variables (month and two months intervals) from September of the previous year to December of the current year.

The climatic signal was also investigated in the IADFs frequencies, by calculating the correlations between IADFs frequency and mean temperature and precipitation. Not all the IADFs types presented a normal distribution, thus Spearman's correlations were used. The correlations between IADFs frequency and the climatic variables were analyzed from February to December. Both analyses were performed monthly and for two months intervals.

\section{Results}

\subsection{Tree-ring width and climate}

The raw and residual tree-ring chronologies for the Azores P. pinaster are shown in Fig. 4. The descriptive statistics of the chronologies for the entire period of study (1954 \& 2010) and for the common interval analysis (1961 \& 2010) are present in Table 1 . The average tree-ring width was of $3.75 \mathrm{~mm}$, with a mean sensitivity of 0.26 , demonstrating that the series were not complacent. The express population signal (EPS) was above the critical value of 0.85 proposed by Wigley et al. (1984) for both chronologies.

Regarding the climate correlations, maritime pine tree-ring width responded positively to April \& May precipitation (Fig. 5). When 

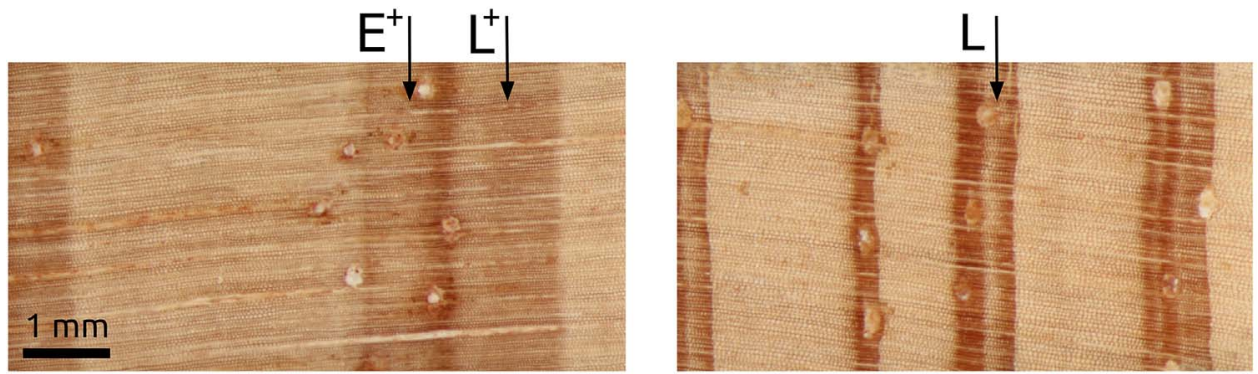

Fig. 3. Intra-annual density fluctuations (IADFs) observed in Pinus pinaster and defined according to its position within the ring. The arrows indicate the position of each type of IADF within the tree-ring. Photographs were taken at $80 \times$ magnification. combining two months, tree-ring width showed a significant positive correlation with March \& April, April \& May and May \& June.

Regarding the NAO and SLP variables, negative relations were observed between tree-ring width and NAO and SLP variables in May (Fig. 6). Regarding the combination of two months, tree-ring width responded negatively to SLP in previous November \& December, April \& May and May \& June, whereas NAO only triggered a negative response in tree-ring width in May \& June.

\subsection{IADFs and climate}

Intra-annual density fluctuations were present in $85 \%$ of the tree rings analyzed (Table 2). The most frequent IADF observed was type $\mathrm{L}$ with a frequency of $67.9 \%$ (Table 2). IADF type $\mathrm{E}^{+}$presented a frequency of $24.9 \%$ and type $\mathrm{L}^{+}$of $25.3 \%$. Since it was frequent to observe more than one type of IADF per tree ring the combinations $\mathrm{E}^{+} \mathrm{L}, \mathrm{E}^{+} \mathrm{L}^{+}$ and $\mathrm{LL}^{+}$were also analyzed. The combination $\mathrm{E}^{+} \mathrm{L}$ was observed in $16.2 \%$; the combination $\mathrm{E}^{+} \mathrm{L}^{+}$in $8.0 \%$ and the combination $\mathrm{LL}^{+}$in $14.6 \%$ of the tree rings. Regarding the frequency of IADFs per calendar year, there was at least one type of IADF in each year (Fig. 7).

The correlation analysis between stabilized IADF frequencies and the meteorological data showed that IADFs type $\mathrm{E}^{+}$had a positive correlation with June precipitation, but a stronger one with February and March mean temperatures (Fig. 8). When combining the climatic variables, a positive correlation was observed with February - March and March - April temperature. IADFs type L responded positively to September precipitation and temperature, and October temperature. When grouping the climatic variables in groups of two, April - May, and September - October precipitation presented a higher correlation. Regarding the temperature signal, a positive correlation was observed between August \& September and September \& October (Fig. 8). The
Table 1

Descriptive statistics of tree-ring width (RAW) and standard (STD) chronologies.

\begin{tabular}{lll}
\hline & RAW & STD \\
\hline Start & 1954 & 1954 \\
End & 2010 & 2010 \\
\# Trees & 22 & 22 \\
\# Cores & 44 & 44 \\
Mean TRW \pm SD & $3.75 \pm 1.76$ & $1 \pm 0.28$ \\
Mean sensitivity & 0.26 & 0.26 \\
First order autocorrelation & 0.71 & 0.28 \\
Mean correlation & & \\
among all radii & 0.61 & 0.37 \\
between trees (rbt) & 0.61 & 0.37 \\
$\quad$ within trees & 0.81 & 0.62 \\
EPS & 0.98 & 0.95 \\
Common Interval Analysis (1961 \& 2010) & \\
\# Trees & 7 & 7 \\
\# Cores & 13 & 13 \\
Mean correlation & & \\
$\quad$ among all radii & & \\
$\quad$ between trees (rbt) & 0.60 & 0.49 \\
$\quad$ within trees & 0.59 & 0.63 \\
EPS & 0.76 & 0.90 \\
\hline
\end{tabular}

IADFs type $\mathrm{L}^{+}$responded positively to precipitation in August and November, and October \& November (Fig. 8).

Combining two types of IADFs (e.g. $\mathrm{E}^{+} \mathrm{L}, \mathrm{E}^{+} \mathrm{L}^{+}$and $\mathrm{LL}^{+}$) did not improve the climatic signal. For instance, the type $\mathrm{E}^{+} \mathrm{L}$ showed no significant climatic correlations and type $\mathrm{LL}^{+}$only presented a positive correlation with November precipitation (data not shown).

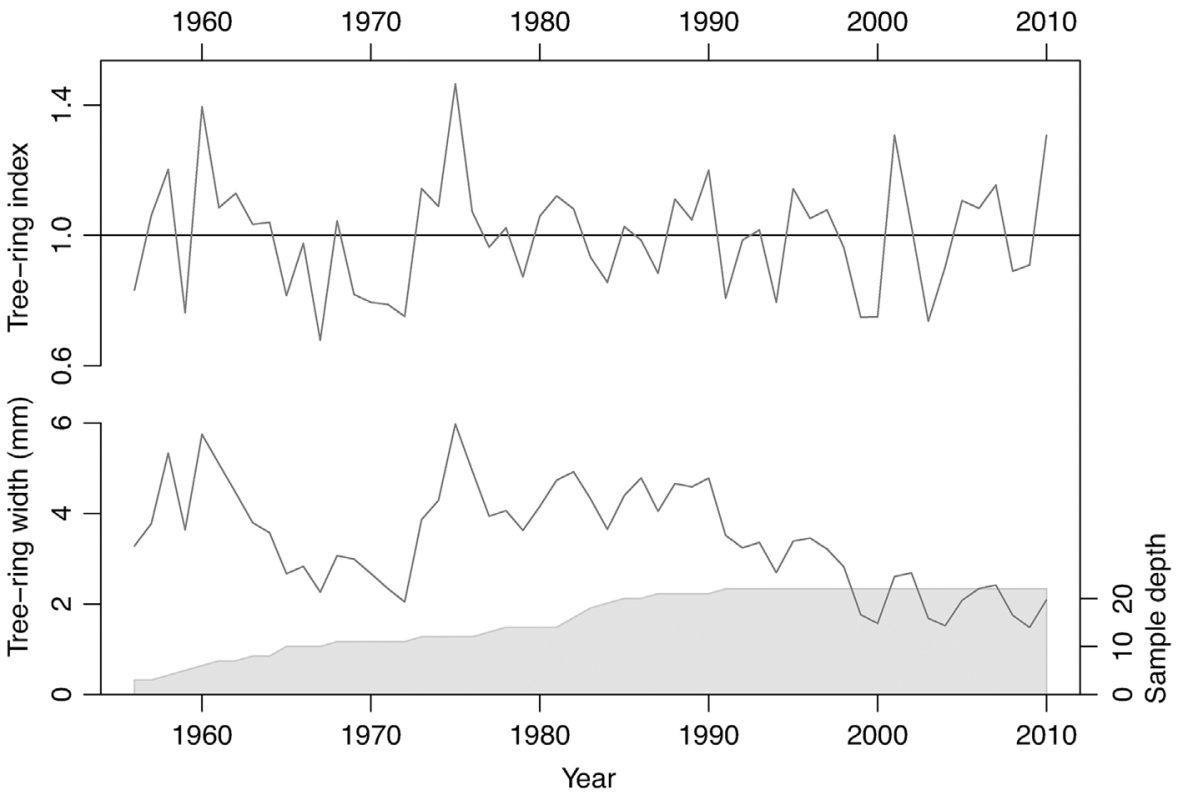

Fig. 4. Residual and raw tree-ring width chronology of Pinus pinaster with sample depth. 


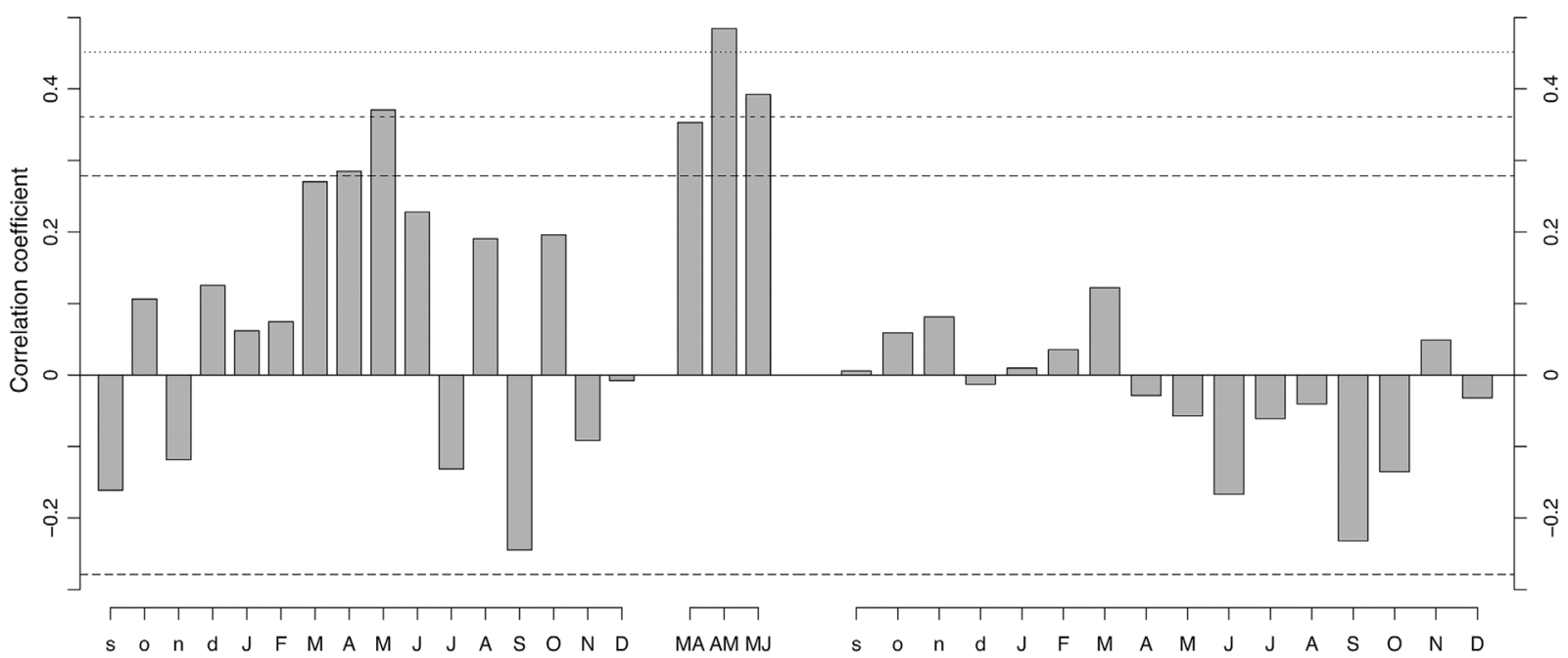

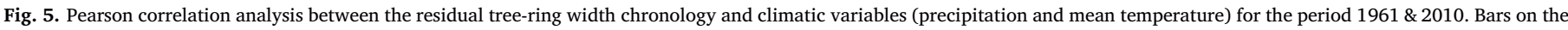
right side represent two months intervals. Horizontal lines represent significance levels at $p=0.05 ; p=0.01 ;$ and $p=0.001$.

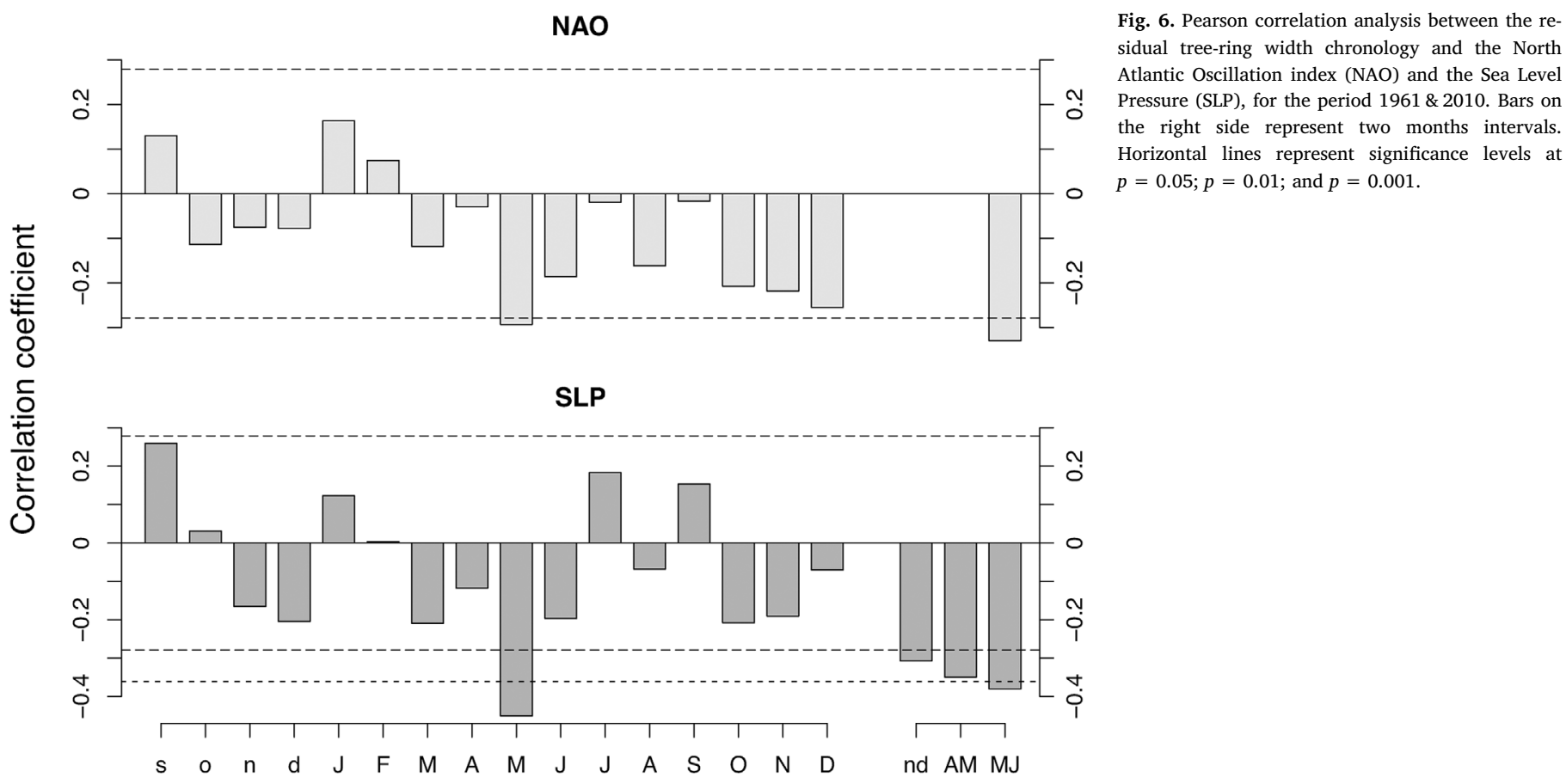

\section{Discussion}

There are only a few dendrochronological studies performed on oceanic islands (Battipaglia et al., 2010; Copenheaver et al., 2010), and even less on the Macaronesia biogeographical region (Jonsson et al., 2002; Pérez-De-Lis et al., 2011; Rozas et al., 2013, 2011b). Macaronesia presents a variety of climatic conditions but the potential for dendrochronological studies has only been explored in the Canary Islands. This is the first dendrochronological study performed in the Azores Archipelago, characterized by a Mediterranean climate with strong oceanic influence.

The samples of maritime pine collected in the Pico Island were difficult to cross-date, since the border between tree rings was not always clear. This unclear border could be due to the climatic characteristics of the Azores Archipelago. Its mild temperatures and high precipitation throughout the year could, in some years, create the climatic conditions for continuous tree growth. According to the climatic data, temperatures in the Azores are never below $10^{\circ} \mathrm{C}$ which according to xylogenesis studies is the limiting temperature for cambial activity (Rossi et al., 2008), suggesting that cambial activity could continue during winter. Non-stopping cambial activity has been reported in the Mediterranean region by Cherubini et al. (2003). In fact, xylogenesis studies in Portugal have shown that maritime pine presents an extended period of cambial activity (from February to November), with lignification lasting until February of the next year (Vieira et al., 2014a). Xylogenesis studies are necessary to confirm whether maritime pine in the Azores can present cambial activity without a clear hiatus during milder winters.

Despite the difficulties in cross-dating the tree-ring series of maritime pine from Pico Island, the chronology presented high values of EPS and rbt which are indicative of the quality and representativeness of the chronology (Wigley et al., 1984). Tree-ring width was enhanced by precipitation from March to June, which had also been reported for this species growing in the Iberian Peninsula (Bogino and Bravo, 2008; 
Table 2

Descriptive statistics of IADFs distribution for the common interval (1961 \& 2010).

\begin{tabular}{ll}
\hline Descriptive statistics of IADF distribution & \\
\hline Number of cores & 44 \\
Cores with IADFs & 44 \\
Number of rings analyzed & 1531 \\
Rings with IADFs & $1301(84.97 \%)$ \\
Rings with IADF type E & $149(9.7 \%)$ \\
Rings with IADF type $\mathrm{E}^{+}$ & $381(24.9 \%)$ \\
Rings with IADF type $\mathrm{L}^{+}$ & $1039(67.9 \%)$ \\
Rings with IADF type $\mathrm{L}^{+}$ & $387(25.3 \%)$ \\
Rings with IADF type $\mathrm{E}^{+} \mathrm{L}$ & $248(16.2 \%)$ \\
Rings with IADF type $\mathrm{E}^{+} \mathrm{L}^{+}$ & $122(8.0 \%)$ \\
Rings with IADF type $\mathrm{LL}^{+}$ & $223(14.6 \%)$ \\
\# Trees & 22 \\
\# Cores & 44 \\
Mean correlation & \\
among all radii & 0.28 \\
between trees (rbt) & 0.28 \\
within trees & 0.41 \\
EPS & 0.93 \\
\hline
\end{tabular}

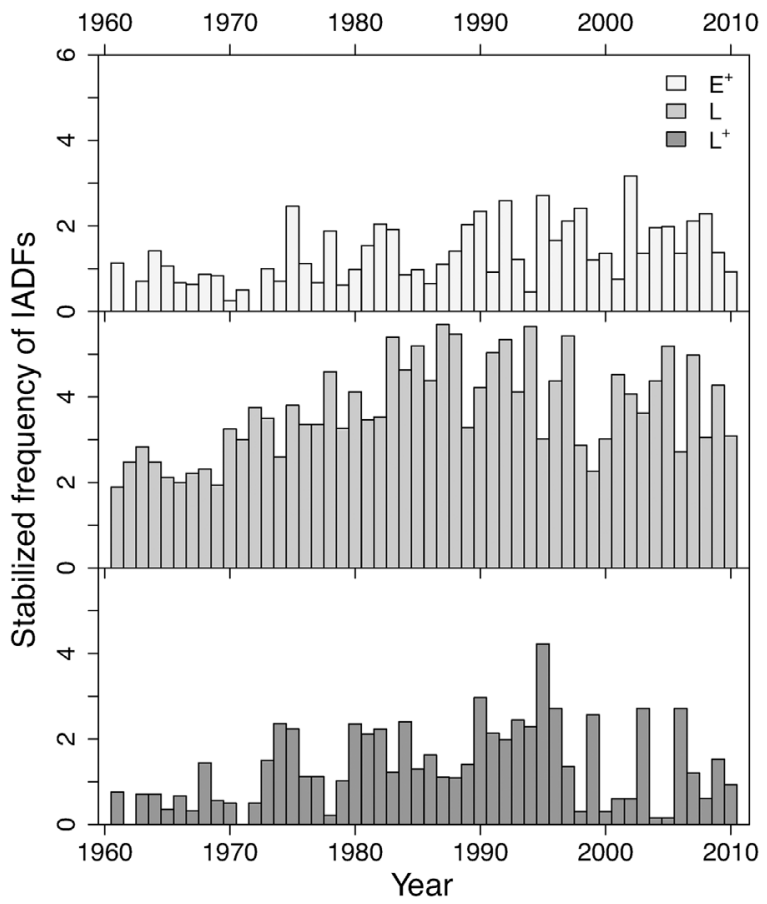

Fig. 7. Stabilized frequency of the different types of intra-annual density fluctuations over time.

Campelo et al., 2013, 2007; Vieira et al., 2009). In fact, xylogenesis studies in maritime pine have determined that, although new tracheids start to differentiate in March, the highest rate of cell production is only attained in May (Vieira et al., 2014a). Water availability is crucial for the process of cell division and enlargement, which is largely mediated by turgor pressure (Kutschera and Niklas, 2013; Wei and Lintilhac, 2003). Pinus canariensis growing on the leeward slope of the Tenerife Island also responded positively to precipitation from March to May (Rozas et al., 2013), indicating the importance of spring precipitation in the Macaronesia region. A positive response to winter precipitation was also found in $P$. canariensis and in other pine species growing in the Iberian Peninsula (Campelo et al., 2013; De Luis et al., 2009; Nabais et al., 2014; Rozas et al., 2011c; Vieira et al., 2009). This signal, however, was not observed in the trees growing in the Azores. The lack of a winter precipitation signal suggests that trees do not rely on soil water reserves during the growing season. This lack of signal in winter is probably due to the abundant precipitation throughout the growing season and also due to a low soil water holding capacity (Cruz and Oliveira Silva, 2001).

Regarding the response of tree-ring width to the large-scale circulation mode NAO, a negative response was observed with the index in May \& June, the opposite of what was observed with precipitation. This correlation was expected since NAO has a major impact on the seasonal precipitation over the North Atlantic region and the Azores (Hernández et al., 2016; Trigo et al., 2008) and because there was a negative correlation between NAO and precipitation during the study period (Hernández et al., 2016). A negative correlation between NAO and treering width was also observed in $P$. canariensis growing in Tenerife (Rozas et al., 2013). The response of SLP was similar to the one observed in NAO, but stronger. NAO is the difference in the atmospheric pressure between the Azores high and the Icelandic low (Wanner et al., 2001), thus it is expected that the correlation with the SLP in the Azores would present a higher score than with NAO.

More than $85 \%$ of the tree rings of maritime pine from Pico Island showed IADFs. The formation of IADFs has been associated with changing climatic conditions within the growing season (Campelo et al., 2007; Wimmer, 2002) but also with wider (Campelo et al., 2013) and/or younger tree-rings (Vieira et al., 2009). In fact, the average treering width of maritime pine in Pico Island was $3.75 \mathrm{~mm}$, wider than the average observed in continental Portugal for the same species with approximately the same cambial age $(2.82 \mathrm{~mm}, 53$ years; Campelo et al., 2013). Wider and younger tree rings are associated with higher rates of cell production and/or a longer growing season (Lupi et al., 2010; Vieira et al., 2014b). Higher frequency of IADFs has also been associated with higher levels of precipitation under Mediterranean climate (Nabais et al., 2014; Rozas et al., 2011a; Zalloni et al., 2016). Pico Island shows high levels of precipitation and since temperature is not a limiting factor, the growing season is potentially longer, thus more cells could be under differentiation, increasing the probability of IADF formation.

IADFs were identified according to their position within the tree ring, with IADFs type $\mathrm{E}^{+}$representing a smooth transition from earlyto latewood; IADFs type L, showing earlywood-like cells within latewood; and IADFs type $\mathrm{L}^{+}$visually defined by earlywood-like cells between latewood and earlywood of the next tree ring. Interestingly, IADFs showed different climatic signals, when compared with tree-ring width. When comparing the precipitation signal of IADFs types $\mathrm{E}^{+}, \mathrm{L}$ and $\mathrm{L}^{+}$it was possible to observe a timeline: type $\mathrm{E}^{+}$presented a positive correlation with June precipitation; type L with September; and type $\mathrm{L}^{+}$with August and November precipitation. This observation reinforces previous studies showing that the position of the IADF within the tree ring is related to the timing of the triggering factor and that the inclusion of IADFs in dendrochronology studies could potentially improve the climatic signal (Campelo et al., 2007; De Micco et al., 2016).

The frequencies of IADFs formed in the Azores were different from what was previously observed in maritime pine growing in continental Portugal. In the Azores IADFs type $\mathrm{E}^{+}$was observed in $25 \%$ of the tree rings observed, whereas in continental Portugal it was rarely present (Vieira et al., 2010). The IADF type $\mathrm{E}^{+}$is visually characterized by a gradual transition from early- to latewood, thus it represents a gradual transition from spring to summer. Actually the positive correlation with June precipitation reinforces the hypothesis that the cambium delays the transition from earlywood to latewood (Carvalho et al., 2015). Additionally, IADF type $\mathrm{E}^{+}$also showed a positive correlation with the temperature of February and March indicating that a warmer spring also induced a gradual decrease in the lumen size of tracheids.

The latewood IADF type L was the most frequently observed. In the Mediterranean region IADF type $\mathrm{L}$ is associated with a combination of summer drought followed by autumn precipitation (Campelo et al., 2007; Rozas et al., 2011a; Zalloni et al., 2016). During the summer period the differentiation of new xylem cells stops. However the return of favorable conditions in early autumn can trigger the resumption of 


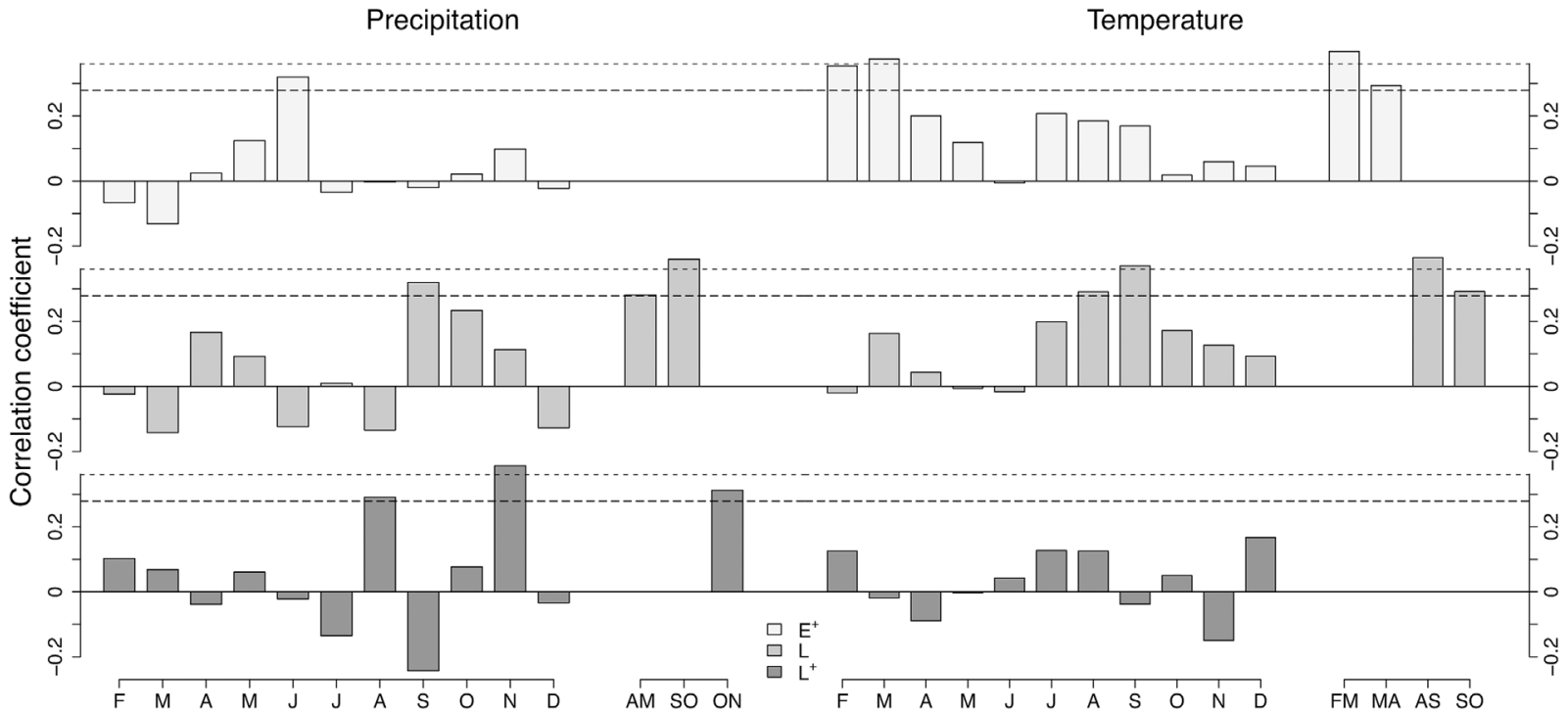

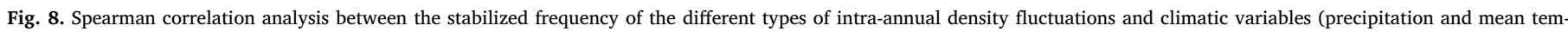
perature) for the period $1961 \& 2010$. Bars on the right side represent two months intervals. Horizontal lines represent significance levels at $p=0.05$ and $p=0.01$.

growth (Vieira et al., 2017, 2015). This second growth pulse is often associated with the formation of latewood IADFs (Carvalho et al., 2015; Vieira et al., 2017, 2015). In the Azores although summer drought is not as pronounced as in the Mediterranean region, IADFs formation were triggered by higher summer temperatures associated with rainfall events in autumn, as observed in pine species from the Mediterranean region (Campelo et al., 2007; Novak et al., 2013; Zalloni et al., 2016).

The analysis of a combination of more than one type of IADF, when present in the same tree ring, did not improve the climatic signal. In fact in the cases studied, IADFs $\mathrm{E}^{+} \mathrm{L}, \mathrm{E}^{+} \mathrm{L}^{+}$and $\mathrm{LL}^{+}$, the signal was worse than the one obtained for each IADF individually. This observation suggests that even if more than one IADF type is present in the same tree ring, its climatic signal is independent.

\section{Conclusion}

To our knowledge, this is the first dendrochronological study in the Azores Archipelago. Tree rings did not always present a clear boundary, suggesting that in those years there was continuous cambial activity during winter. However, it was possible to crossdate the tree-ring series and to produce a mean chronology with a high common signal. Treering width presented a strong positive correlation with spring precipitation and a negative one with NAO in May \& June, as observed in $P$. canariensis growing in Tenerife, suggesting a regional signal.

A high frequency of IADFs, especially in latewood, was observed in maritime pine. Latewood IADFs usually imply that there is a resumption of growth after the summer drought. Although the Pico Island presents a moderate summer drought, when followed by above average precipitation from September to November it induces the formation of latewood IADFs in maritime pine. The different IADFs types presented different climatic signals according to their position within the tree ring: IADFs type $\mathrm{E}^{+}$were positively correlated with June precipitation and February \& March temperature; IADFs type L were positively correlated with September precipitation and temperature; and IADFs type $\mathrm{L}^{+}$with November precipitation. The identification of IADFs according to their relative position inside tree-rings and their associated climatic signals can provide further information of climate conditions over the growing season.

\section{Acknowledgments}

This study was supported by the Fundação para a Ciência e a
Tecnologia, Ministério da Educação e Ciência (FCT) co-financed by Compete, through the project PTDC/AAC-CLI/103361/2008. Filipe Campelo (SFRH/BPD/111307/2015) and Joana Vieira (SFRH/BPD/ $105656 / 2015)$ were supported by postdoctoral research grants from FCT with funds from POPH (Portuguese Operational Human Potential Program), QREN Portugal (Portuguese National Strategic Reference Framework) and FSE (European Social Fund). The authors would like to thank Maria João Silva for technical support. The authors would like to thank the two anonymous reviewers and editor for helpful comments and suggestions on an earlier version of the manuscript.

\section{References}

Battipaglia, G., De Micco, V., Brand, W.A., Linke, P., Aronne, G., Saurer, M., Cherubini, P., 2010. Variations of vessel diameter and $\delta 13 \mathrm{C}$ in false rings of Arbutus unedo L. reflect different environmental conditions. New Phytol. 188, 1099-1112. http://dx.doi.org/ 10.1111/j.1469-8137.2010.03443.x.

Battipaglia, G., Campelo, F., Vieira, J., Grabner, M., De Micco, V., Nabais, C., Cherubini, P., Carrer, M., Bräuning, A., Cufar, K., Di Filippo, A., García-González, I., Koprowski, M., Klisz, M., Kirdyanov, A.V., Zafirov, N., de Luis, M., 2016. Structure and function of intra-annual density fluctuations: mind the gaps. Front. Plant Sci. 7 (595). http:// dx.doi.org/10.3389/fpls.2016.00595.

Bogino, S., Bravo, F., 2008. Growth response of Pinus pinaster Ait. to climatic variables in central Spanish forests. Ann. For. Sci. 65, 506. http://dx.doi.org/10.1051/forest.

Briffa, K.R., Cook, E.R., 1990. Methods of Response Function Analysis, Methods of Dendrochronology: Applications in the Environmental Sciences. Kluwer Academic Publishers, Boston.

Bunn, A., 2008. A dendrochronology program library in R (dplR). Dendrochronologia 26, 115-124. http://dx.doi.org/10.1016/j.dendro.2008.01.002.

Campelo, F., Nabais, C., Freitas, H., Gutierrez, E., 2007. Climatic significance of tree-ring width and intra-annual density fluctuations in Pinus pinea from a dry Mediterranean area in Portugal. Ann. For. Sci. 64, 229-238. http://dx.doi.org/10.1051/forest.

Campelo, F., García-González, I., Nabais, C., 2012. DetrendeR-a graphical user interface to process and visualize tree-ring data using R. Dendrochronologia 30, 57-60. http:// dx.doi.org/10.1016/j.dendro.2011.01.010.

Campelo, F., Vieira, J., Nabais, C., 2013. Tree-ring growth and intra-annual density fluctuations of Pinus pinaster responses to climate: does size matter? Trees Struct. Funct. 27, 763-772. http://dx.doi.org/10.1007/s00468-012-0831-3.

Campelo, F., Vieira, J., Battipaglia, G., de Luis, M., Nabais, C., Freitas, H., Cherubini, P., 2015. Which matters most for the formation of intra-annual density fluctuations in Pinus pinaster: age or size? Trees Struct. Funct. 29, 237-245. http://dx.doi.org/10. 1007/s00468-014-1108-9.

Campelo, F., Nabais, C., Carvalho, A., Vieira, J., 2016. tracheideR-an R package to standardize tracheidograms. Dendrochronologia 37, 64-68. http://dx.doi.org/10. 1016/j.dendro.2015.12.006.

Carvalho, A., Nabais, C., Vieira, J., Rossi, S., Campelo, F., 2015. Plastic response of tracheids in Pinus pinaster in a water-limited environment: adjusting lumen size instead of wall thickness. PLoS One 10,1-14. http://dx.doi.org/10.1371/journal.pone. 0136305.

Cherubini, P., Gartner, B.L., Tognetti, R., Braker, O.U., Schoch, W., Innes, J.L., Gartner, B.L., Tognetti, R., Braker, O.U., Schoch, W., Innes, J.L., Gartner, B.L., Tognetti, R. 
Braker, O.U., Schoch, W., Innes, J.L., 2003. Identification, measurement and interpretation of tree rings in woody species from mediterranean climates. Biol. Rev. 78, $119-148$.

Copenheaver, C.A., Gartner, H., Schafer, I., Vaccari, F.P., Cherubini, P., Gärtner, H., Schäfer, I., Vaccari, F.P., Cherubini, P., 2010. Drought-triggered false ring formation in a Mediterranean shrub. Botany 88, 545-555. http://dx.doi.org/10.1139/B10-029.

Cruz, J.V., Oliveira Silva, M., 2001. Hydrogeologic framework of Pico Island, Azores, Portugal. Hydrogeol. J. 9, 177-189. http://dx.doi.org/10.1007/s100400000106.

Cunha, R.T., Rangel, B., Vieira, O., Rego, I.E., 2010. Is it really haening here? A study of climate change perception in the Azores. WIT Transactions on Ecology and the Environment. WIT Presspp. 113-120. http://dx.doi.org/10.2495/ISLANDS100101.

De Luis, M., Novak, K., Čufar, K., Raventos, J., 2009. Size mediated climate-growth relationships in Pinus halepensis and Pinus pinea. Trees Struct. Funct. 23, 1065-1073. http://dx.doi.org/10.1007/s00468-009-0349-5.

De Micco, V., Campelo, F., de Luis, M., Bräuning, A., Grabner, M., Battipaglia, G., Cherubini, P., 2016. Intra-annual density fluctuations in tree rings: how, when, where and why? IAWA J. 37, 232-259. http://dx.doi.org/10.1163/22941932-20160132.

EUFORGEN, 2009. Distribution map of Pinus pinaster [WWW Document]. www.euforgen. org.

Governo Regional dos Açores, 2002, Parque Florestal de Santa Luzia [WWW Document]. Direcção Reg. Recur. Florestais, Serviço Florest. do Pico. URL http://drrf-sraa.azores. gov.pt/areas/reservas-recreio/Documents/RFR_Santa_Luzia_flyer_pt.pdf.

Hernández, A., Kutiel, H., Trigo, R.M., Valente, M.A., Sigró, J., Cropper, T., Santo, F.E., 2016. New Azores archipelago daily precipitation dataset and its links with largescale modes of climate variability. Int. J. Climatol. 4454, 4439-4454. http://dx.doi. org/10.1002/joc. 4642

Jonsson, S., Gunnarson, B., Criado, C., Geology, Q., Laguna, L., 2002. Drought is the major limiting factor for tree-ring growth of high-altitude Canary Island pines on Tenerife. Geogr. Ann. Ser. A: Phys. Geogr. 84A, 51-71. http://dx.doi.org/10.1111/j. 0435-3676.2002.00161.x

Kutschera, U., Niklas, K.J., 2013. Cell division and turgor-driven stem elongation in juvenile plants: a synthesis. Plant Sci. 207, 45-56. http://dx.doi.org/10.1016/j. plantsci.2013.02.004

Lupi, C., Morin, H., Deslauriers, A., Rossi, S., 2010. Xylem phenology and wood production: resolving the chicken-or-egg dilemma. Plant Cell Environ. 33, 1721-1730. http://dx.doi.org/10.1111/j.1365-3040.2010.02176.x.

Madeira, J., 1998. Estudos de neotectónica nas ilhas do Faial, Pico e S. Jorge: uma contribuição para o conhecimento geodinâmico da junção tripla dos Açores. Faculdade de Ciências da Universidade de Lisboa.

Myers, N., Mittermeier, R.A., Mittermeier, C.G., da Fonseca, G.A.B., Kent, J., 2000. Biodiversity hotspots for conservation priorities. Nature 403, 853-858. http://dx.doi. org $/ 10.1038 / 35002501$.

Nabais, C., Campelo, F., Vieira, J., Cherubini, P., 2014. Climatic signals of tree-ring width and intra-annual density fluctuations in Pinus pinaster and Pinus pinea along a latitudinal gradient in Portugal. Forestry 87, 598-605. http://dx.doi.org/10.1093/ forestry/cpu021.

Novak, K., Čufar, K., de Luis, M., Sánchez, M.A.S., Raventós, J., 2013. Age, climate and intra-annual density fluctuations in Pinus halepensis in Spain. IAWA J. 34, 459-474. http://dx.doi.org/10.1163/22941932-00000037.

Osborn, T.J., Jones, P.D., Briffa, K.R., 1997. Adjusting variance for samplesize in tree-ring chronologies and other regional mean time series. Dendrochronologia 15, 89-99.

Pérez-De-Lis, G., García-González, I., Rozas, V., Arévalo, J.R., 2011. Effects of thinning intensity on radial growth patterns and temperature sensitivity in Pinus canariensis afforestations on Tenerife Island. Spain. Ann. For. Sci. 68, 1093-1104. http://dx.doi. org/10.1007/s13595-011-0125-8.

Rinn, F., 2003. TSAP-Win: Time series analysis and presentation for dendrochronology and related applications. Heidelberg.

Rossi, S., Deslauriers, A., Gričar, J., Seo, J.W., Rathgeber, C.B.K., Anfodillo, T., Morin, H., Levanic, T., Oven, P., Jalkanen, R., 2008. Critical temperatures for xylogenesis in conifers of cold climates. Glob. Ecol. Biogeogr. 17, 696-707. http://dx.doi.org/10 1111/j.1466-8238.2008.00417.x.

Rozas, V., Garcia-Gonzalez, I., Zas, R., 2011a. Climatic control of intra-annual wood density fluctuations of Pinus pinaster in NW Spain. Trees Struct. Funct. 25, 443-453. http://dx.doi.org/10.1007/s00468-010-0519-5.

Rozas, V., Pérez-de-Lis, G., García-González, I., Arévalo, J.R., 2011b. Contrasting effects of wildfire and climate on radial growth of Pinus canariensis on windward and leeward slopes on Tenerife, Canary Islands. Trees Struct. Funct. 25, 895-905. http://dx. doi.org/10.1007/s00468-011-0564-8.

Rozas, V., Zas, R., García-González, I., 2011c. Contrasting effects of water availability on Pinus pinaster radial growth near the transition between the Atlantic and Mediterranean biogeographical regions in NW Spain. Eur. J. For. Res. 130, 959-970. http://dx.doi.org/10.1007/s10342-011-0494-4.

Rozas, V., García-González, I., Pérez-De-Lis, G., Arévalo, J.R., 2013. Local and large-scale climatic factors controlling tree-ring growth of Pinus canariensis on an oceanic island. Clim. Res. 56, 197-207. http://dx.doi.org/10.3354/cr01158.

Santos, F., Valente, M., Miranda, P., Aguiar, A., Azevedo, E., Tomé, A., Coelho, F., 2004 Climate change scenarios in the Azores and Madeira Islands. World Resour. Rev. 16, 473-491.

Stokes, M.A., Smiley, T.C., 1996. An Introduction to Tree-Ring Dating. The University of Arizona Press, Tucson.

Trigo, R.M., Valente, M.A., Trigo, I.F., Miranda, P.M.A., Ramos, A.M., Paredes, D., GarcíaHerrera, R., 2008. The impact of North Atlantic wind and cyclone trends on European precipitation and significant wave height in the Atlantic. Ann. N. Y. Acad. Sci. 1146, 212-234. http://dx.doi.org/10.1196/annals.1446.014.

Vieira, J., Campelo, F., Nabais, C., 2009. Age-dependent responses of tree-ring growth and intra-annual density fluctuations of Pinus pinaster to Mediterranean climate. Trees Struct. Funct. 23, 257-265. http://dx.doi.org/10.1007/s00468-008-0273-0.

Vieira, J., Campelo, F., Nabais, C., 2010. Intra-annual density fluctuations of Pinus pinaster are a record of climatic changes in the western Mediterranean region. Can. J. For Res. 40, 1567-1575. http://dx.doi.org/10.1139/X10-096.

Vieira, J., Rossi, S., Campelo, F., Freitas, H., Nabais, C., 2014a. Xylogenesis of Pinus pinaster under a Mediterranean climate. Ann. For. Sci. 71, 71-80. http://dx.doi.org/10. 1007/s13595-013-0341-5.

Vieira, J., Rossi, S., Campelo, F., Nabais, C., 2014b. Are neighboring trees in tune? Wood formation in Pinus pinaster. Eur. J. For. Res. 133, 41-50. http://dx.doi.org/10.1007/ s10342-013-0734-x.

Vieira, J., Campelo, F., Rossi, S., Carvalho, A., Freitas, H., Nabais, C., 2015. Adjustment capacity of maritime pine cambial activity in drought-prone environments. PLoS One 10, 1-15. http://dx.doi.org/10.1371/journal.pone.0126223.

Vieira, J., Nabais, C., Rossi, S., Carvalho, A., Freitas, H., Campelo, F., 2017. Rain exclusion affects cambial activity in adult maritime pines. Agric. For. Meteorol. 237, 303-310. http://dx.doi.org/10.1016/j.agrformet.2017.02.024.

Wanner, H., Brönnimann, S., Casty, C., Gyalistras, D., Luterbacher, J., Schmutz, C., Stephenson, D.B., Xoplaki, E., 2001. North Atlantic oscillation-concepts and studies 1. Surv. Geophys. 22, 321-381.

Wei, C., Lintilhac, P.M., 2003. Loss of stability-a new model for stress relaxation in plant cell walls. J. Theor. Biol. 224, 305-312. http://dx.doi.org/10.1016/S0022-5193(03) 00167-X.

Wigley, T.M., Jones, P.D., Briffa, K., 1984. On the average value of correlated time series, with applications in dendroclimatology and hydrometeorology. J. Clim. Appl. Met. 23, 201-213.

Wimmer, R., 2002. Wood anatomical features in tree-rings as indicators of environmental change. Dendrochronologia 20, 21-36.

Zalloni, E., Luis, M., De Campelo, F., Novak, K., Micco, V., De Filippo, A., Di Vieira, J., Nabais, C., Rozas, V., Battipaglia, G., 2016. Climatic signals from intra-annual density fluctuations frequency in Mediterranean Pines at a regional scale. Front. Plant Sci. 7 , 1-11. http://dx.doi.org/10.3389/fpls.2016.00579. 